\title{
The Future of Single-use Paper Coffee Cups: Current Progress and Outlook
}

\author{
Nick Triantafillopoulos ${ }^{a}$ and Alexander A. Koukoulas ${ }^{b, *}$
}

\begin{abstract}
The expanded use of environmentally friendly and sustainable foodservice packaging continues to be a prime focus of stakeholders across the foodservice value chain. Paper-based coffee cups is one product segment where effective recycling of waste cups remains elusive. As a result, material substitutes for polyethylene liners are emerging to solve the problem of waste cups. In this paper, current and emerging commercial material technologies used in the production of paper-based coffee cups that are readily recyclable with other paper grades are reviewed. Many of these material solutions are also compostable. Special attention is paid to the rapidly evolving, alternative large-scale production of bioplastics. Multiple efforts to effectively develop a more environmentally friendly paper cup are also examined. It is clear that broad adoption of proposed solutions will require an integrated commitment and approach to circular economics. Specifically, this includes: changes in consumer behavior; brand owner initiatives to meet sustainability goals; governmental policies that limit or forbid use of fossil-based cups; and easily accessible infrastructures at the consumer level for the collection, separation, and processing of biodegradable cups.
\end{abstract}

Keywords: Paper coffee cups; Sustainable foodservice packaging; Barrier coatings; Waterbased coatings; Bioplastics

Contact information: a: Arditos Innovation LLC, San Diego, CA, USA; b: A2K Consultants LLC, $2 \mathrm{~N}$. Fahm St., 2981, Savannah, GA, USA 31402; *Corresponding author: alex@a2kconsultants.com

\section{INTRODUCTION}

The popularity of cafés and the like have created a worldwide explosion in the consumption of out-of-home $(\mathrm{OOH})$ coffee and coffee beverages. Recent surveys estimate the market size for single-use $\mathrm{OOH}$ hot paper coffee cups at 118 billion units per year with a compounded annual growth rate (CAGR) of $1.8 \%$ to reach 294 billion units by 2025 (iMarc 2020). Between 2012 and 2017, the number of coffee shops increased 16\% and $28 \%$ in the US and UK, respectively. This growth is expected to continue, driven by the demand for convenience by consumers (Chaudhuri 2018). Hectic, busy lifestyles lead cashrich and time-poor consumers to use single use $\mathrm{OOH}$ cups. This trend is expected to drive annual consumption of paperboard cupstock from 2.2 million tons ( $\mathrm{mt}$ ) currently to $6.8 \mathrm{mt}$ by 2025, a three-fold increase (Hämäläinen 2019). Although single-use hot coffee beverages are sometimes offered in cups made from expanded polystyrene (EPS), this review is only focused on fiber-based paper cups made from cellulosic fibers and a polymeric barrier liner.

The United States leads all nations in the consumption of OOH paper-based coffee cups: 136 million cups per day. This is followed by China (27.4 million), Russia (16.4 million), Germany (7.2 million), Britain (7.0 million), and Australia (2.7 million) (Ma 2018). Most of the used coffee cups end up in landfills, where they do not biodegrade 
(Rodden 2018). Although packaging utilizes sustainable, and sometimes recycled, wood fiber to make the paperboard cupstock, the cups are commonly lined with polyethylene (PE) coatings to create the required limited-term hot liquid, oil, and fatty acid resistant barrier functionalities, as well as to maintain cup integrity and preserve coffee aroma required for ultimate customer experience. Paper coffee cups are used for an average of 13 min before being tossed out. In spite of efforts and incremental progress in developed economies to increase recycling rates, we estimate that less than $1 \%$ of used paper coffee cups are recycled worldwide because of

(a) ineffective or inconsistent recycling schemes among communities and venues,

(b) the perception that paper coffee cups are made from a difficult-to-recycle mix of paper and plastic, and

(c) the inability of many recycling facilities to commit to processing foodcontaminated waste streams.

Recovery of used coffee cups is low due to the limited availability of systematic collecting, sorting, and processing to recycling or industrial composting facilities. In contrast, fossilbased plastic-coated paper coffee cups take more than 20 years to decompose in landfills and are major contributors to the pollution of land, rivers, and oceans.

Consumers, especially those grouped as Millennials and Generation Z, have become increasingly sensitive to the environmental impact of their product choices. This has challenged manufacturers and brand owners to re-examine end-of-life options for paper coffee cups including the collection, separation, and recycling of the different cup components. In practice, most paper coffee cups are either disposed improperly or mixed in with waste streams that are eventually landfilled. Most plastics, including PE, do not readily degrade in the environment, relying on a combination of long duration processes such as photodegradation, thermo-oxidative degradation, oxo-biodegradation, and hydrolytic degradation to completely decompose (Webb et al. 2013). Consequently, the popular single-use $\mathrm{OOH}$ paper coffee cup coated with $\mathrm{PE}$ has become a big target for consumers, brand owners, governments, and companies looking to replace fossil-based plastics with more sustainably derived and environmentally friendly alternatives (Chaudhuri 2018).

\section{Biodegradation}

Biodegradation through composting is an attractive solution to coffee cup end-oflife. Composting is the controlled aerobic biological decomposition of organic matter into a stable, humus-like product called compost (USDA 2010). Unlike degradation, biodegradation relies on microorganisms, such as bacteria and fungi, to metabolize the material so that it completely disintegrates into water, $\mathrm{CO}_{2}$, and decayed organic material or compost. The resulting compost is full of beneficial soil nutrients and is often used as a soil amendment. As with all chemical processes, composting rates are affected by the chemical composition of material, and the time and temperature of the compositing conditions. Under normal composting conditions where the temperature is at least $25^{\circ} \mathrm{C}$ (preferably $35{ }^{\circ} \mathrm{C}$ ), 60 to $90 \%$ of the material will biodegrade within 84 to 180 days, disintegrating into pieces of less than $2 \mathrm{~mm}$ in size. Industrial compositing, which operates at temperatures around 50 to $60{ }^{\circ} \mathrm{C}$, reduces this time to less than one month and it is the most preferred method to biodegrade compostable paper coffee cups and other foodservice packaging (European Bioplastics 2017). However, limited industrial composting facilities are available worldwide. 
Studies have shown that PE-based coffee cups do not readily biodegrade (Brinton et al. 2016). Two-sided PE-coated substrates are even more recalcitrant, as the second plastic layer retards microorganisms from reaching the fibrous component. Micro-plastic fragments are often released from plastic coated cups during degradation and can easily be transferred by surface water into streams and oceans. In contrast, discarding a cup into the ocean takes decades to disintegrate and decompose. As a result, there is keen interest to streamline the collection, sorting, and recycling of $\mathrm{OOH}$ paper coffee cups, while in parallel pursuing substitute barrier technologies that assist compostability and biodegradation.

\section{Topics for Review}

This paper reviews the current state-of-the-art barrier coatings and other technologies used to produce recyclable or biodegradable $\mathrm{OOH}$ paper coffee cups. It discusses efforts to expand coffee cup recyclability and compostability. Focus is placed on worldwide progress in the search for alternatives to plastic barrier coatings and challenges that must be addressed to successfully replace fossil-based PE. The task is formidable, as successful replacement of fossil-based plastic coatings will require cost-effective delivery of all essential barrier and functional cup properties (e.g., heat sealability, anti-blocking, mechanical strength, and thermal insulation) within proven manufacturing processes. Additionally, alternatives to the current cup platform must be economically competitive and contribute to the circular economy. For the purpose of this review, only alternative technologies that have already been commercialized are included. Challenges for recycling paper coffee cups and the emergence of schemes to streamline the process and increase recycling levels are also addressed. Finally, there is discussion of key trends that will affect the substitution of fossil-based barrier plastics.

\section{STRUCTURAL DESIGN OF THE PAPER COFFEE CUP}

Most paper coffee cups are currently made from coated paperboard, or cupstock, which is either single- or double-walled. The barrier coating is typically made from PE, which is extruded or laminated to the paperboard. The cup comprises a paperboard substrate with a basis weight of 150 to $350 \mathrm{~g} / \mathrm{m}^{2}$ and a PE liner of 8 to $20 \mathrm{~g} / \mathrm{m}^{2}$, which has a thickness of about $50 \mu \mathrm{m}$.

Figure 1 shows the essential design elements of a coffee cup: a cylindrical wall portion (A) along a vertical lap seam (B), which joins the end edges (C) and (D) (Mohan and Koukoulas 2004). In this design, a single-sided PE-coated board is formed into a single-wall cup. The outer (top) layer may be coated to enhance printability and heat sealability. The end edges are affixed to one another using conventional methods, typically melt-bonding (hot air or ultrasound).

Paper cups also include a circular rolled rim (F) and a separate circular bottom portion (E) attached and heat sealed to the side wall. The latter is a thicker caliper than the bottom paperboard base. Sometimes, the bottom cupstock is two-side coated with PE for a better seal. Figure 2 is a photograph of a paper coffee cup made using an extruded fossilbased PE coating. 


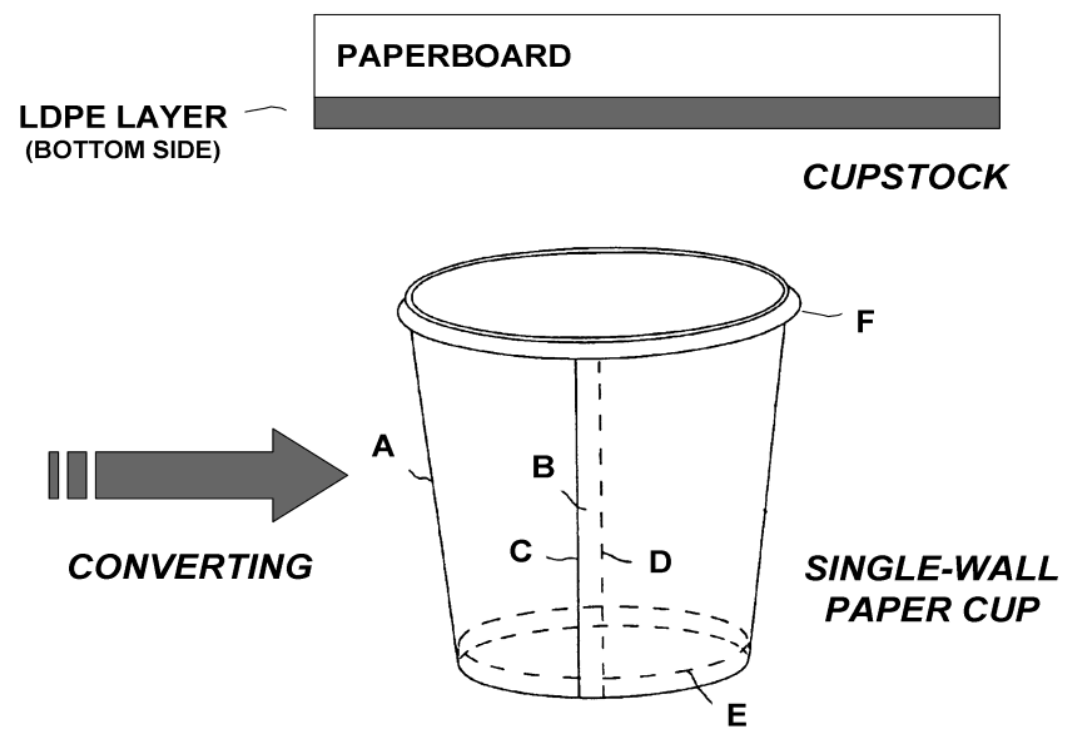

Fig. 1. Design elements of a single-wall paper cup adapted from Mohan and Koukoulas (2004)

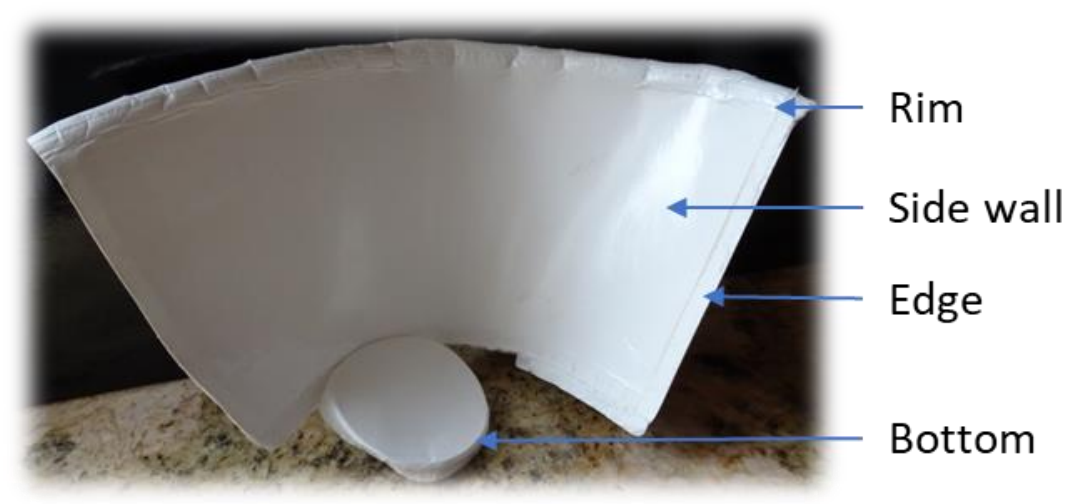

Fig. 2. Single-wall paper cup manufactured by SOLO

Double-wall paper cups have inner and outer paperboard cupstocks separated by an insulating middle layer. A corrugated medium has often been used as a middle layer to add structural rigidity and thermal insulation. In some double-wall cup designs, a combination of layers imparts additional thermal insulation to the cup, either by including an air gap (Fig. 3) or by incorporating polymeric insulating stripes (Fig. 4) between the outer and inner paperboard layers. Such designs remove the need for a clutch or sleeve, have lower maximum wall temperature for "warm touch" without burning the fingers, and allow the contents to stay warm longer, while protecting aroma.

Although it represents between 5\% and 10\% of the weight of the final cup, the inner liner is critical to the end-use performance of the cup and its manufacture. The liner must impart critical resistance to hot and cold liquids, as well as resistance to fatty acids present in milk and cream. It also has an important heat-sealing function, which ensures the integrity of the cup rim, side seam, and cup bottom. Seal elements at exposed edges must be resistant to imbibition from liquids, which will degrade the mechanical integrity of the cup. Additionally, seals must withstand the high temperatures experienced during the serving of hot beverages. 


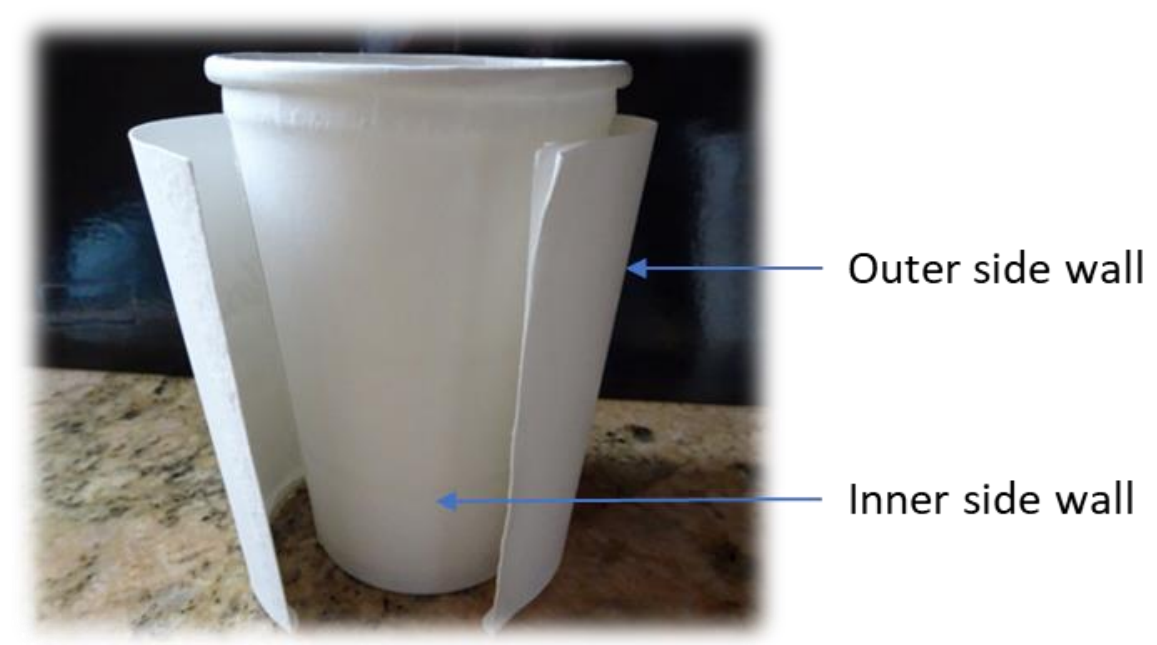

Fig. 3. Double-wall paper cup manufactured by Seda Packaging showing outer wall

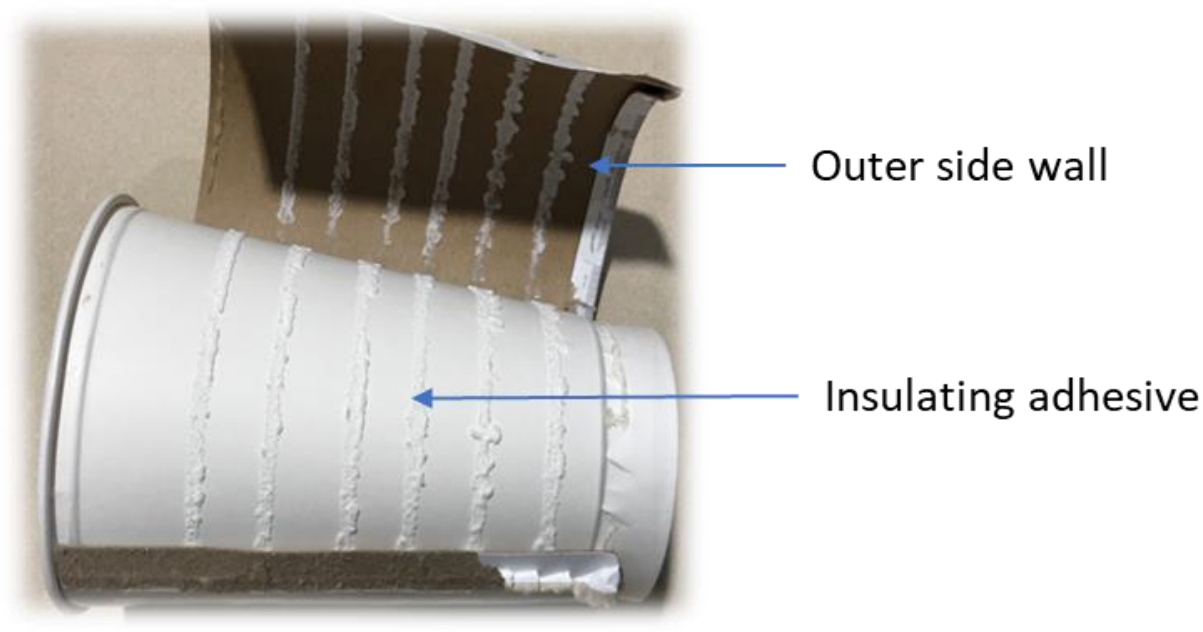

Fig. 4. Double-wall paper cup with Thermolite ${ }^{\mathrm{TM}}$ insulation from LBP Manufacturing

The paperboard used for cupstock will typically contain sizing agents, such as alkyl ketyl dimer (AKD), alkyl succinic anhydride (ASA), or fluorochemicals, to prevent penetration by liquids and lactic acid-containing liquids, such as milk or cream, at exposed surfaces. A challenge of such treatments is poor adhesion of the subsequently applied PE barrier film on to the treated paperboard. Although addition of fluorochemicals at the wetend, water box, or size press is a mature and proven technology to impart water, grease, and oil resistance to paperboard, its use in direct-contact food applications has been declining rapidly due to health concerns (Hogue 2018). Long alkyl chain fluorocarbons, like perfluorooctanesulfonic acid (PFOS) and perfluorooctanoic acid (PFOA), have been replaced by short chain analogues. Compounds with six or fewer fluorinated carbon atoms (i.e., fluorotelomers) work nearly as well as their longer chain versions and they have currently replaced all long chain fluorochemicals (Ritter 2015). Currently, paperboard manufacturers and converters have abandoned making paperboard cupstock containing any type of fluorochemicals because single-use coffee cups have a limited time exposure to coffee oils and fatty acids from milk or creamers. However, other sizing additives are still used. 
The material selection and compositional structure of $\mathrm{OOH}$ paper coffee cups are to a large extent dictated by the process requirements for converting, the required end-use barrier performance, and convenience features. However, the resulting mixture of materials and features also make the cups difficult to recycle.

\section{THE CHANGING DEMANDS OF CONSUMERS}

Consumers often change their minds, so it should not come as a surprise that their views of foodservice items, like coffee cups, have evolved over time. In the 1990s, an analysis of five different types of coffee cups concluded that eliminating disposable cups was costlier and caused greater environmental impact than available disposal options (Hocking 1994). The study examined a range of cup types in terms of regulated environmental requirements, convenience, and cost, and it showed that consumers base their choice of a cup type on aesthetics and convenience rather than perceived environmental impacts. However, that was the '90s. Fast forward to the early $2010 \mathrm{~s}$. During this period, Starbucks tried to implement a program saving 10 cents every time a customer brings his/her own coffee cup, yet only $2 \%$ of their customers took them up on the offer (Minter 2014). At the same time, Starbucks initiated efforts to demonstrate the value and feasibility of paper cup recycling (Kamenetz 2010).

Today, consumer sentiment has changed dramatically, driven by the heightened awareness and concern for the environment, the introduction of favorable regulatory and public policies that ban fossil-based plastics and promote sustainable products, and the desire of brand owners to present a strong eco-centric image to their consumer base, shareholders, and the general public. Increasingly, consumers, especially younger consumers comprising the Millennial and Generation $\mathrm{Z}$ categories, demand brands for sustainable solutions. Moreover, they are willing to alter their buying habits favoring more sustainable packaging. Fossil-based plastics are perceived as environmentally less preferred because they deplete hydrocarbons, are difficult to recycle, and have a large $\mathrm{CO}_{2}$ fingerprint during their complete life cycle. A European survey conducted with a group of 5,900 consumers from 8 countries in March 2020, confirmed this (Tame 2020). Nearly $70 \%$ of consumers are actively taking steps to reduce their use of plastics and $48 \%$ say that they would avoid retailers that are not actively trying to reduce their use of non-recyclable plastic packaging. Fiber-based packaging ranks highest with consumers for sustainability attributes, including home compostable (72\%), better for the environment (62\%), and easier to recycle $(57 \%)$.

Many countries, states, townships, and cities around the world are moving towards banning plastics from $\mathrm{OOH}$ items. Recommendations have been made around the world to remove, or even ban, single-use foodservice packaging, including plastic cups. Examples include policies in the EU and Australia to phase-out single-use plastics by 2023, and in Taiwan by 2030 (Chaudhuri 2018). The Kerala state government in India has gone a step further by including paper coffee cups in their ban of the production, sale, and use of singleuse plastics.

Significant progress has been made at the municipal and regional levels for collecting and sorting waste for recycling. According to BioCycle, the number of curbside collection programs in the USA has increased from 14 in 2014 to 48 in 2017, an 87\% increase (Streeter and Platt 2017). In early 2018, 326 USA communities had access to food waste collection, up from 198 in 2014, a 65\% increase. In a recent report, curbside 
recycling programs capture an estimated 11.9 million tons, which is less than one-third of the total 37.4 million tons of recyclables in the United States (Mouw et al. 2020). The report determined that improvements need to be made in curbside access, participation, and participant capture behavior to feed the circular economy of the future.

Similar and even more intense efforts have been initiated in Europe and the UK. The Paper Cup Recovery \& Recycling Group (PCRRG) leads paper cup recycling to meet the 2016 UK Manifesto Goal: "by 2020 the greater majority of the UK population will have access to information, schemes, and facilities that enable used paper cups to be sustainably recovered and recycled." In their 2017 progress, PCRRG showed that capacity exists to recycle all paper cups currently used in the UK (Reed 2018). The program has made significant inroads: more than 4,500 paper cup recycling points for consumers to return cups in bins and in-store take back; 115 municipalities collect paper cups with paper cartons; 21 waste collectors actively participate in a national recycling program to increase recycling of paper cups and transport them to their reprocessing end markets, up from two last year; four recycling papermills are accepting paper cups, including ACE UK, DS Smith, James Cropper, and Veolia; and at least nine regional councils have started to include paper cups in curbside collection from households. This is in extension of Veolia's national coffee cup solution to make cup recycling possible in offices across the UK in 2017.

\section{Pursuing the Goal of "Zero Waste"}

Another approach is to shift consumers behavior by incentivizing them to not use single-use coffee cups and aim to zero waste. On January 2020, the city of Berkeley in California (USA) imposed a 25-cent tax on disposable coffee cups with the intent of inducing consumers to use their own reusable coffee cup. Cafés are also taking aim at incentives. For example, Nova Familia Coffee (Portland, Oregon, USA) charges customers 25 cents for a disposable to-go cup and gives them a 25-cent discount for bringing their own cup. In its 2018 to 2019 transparency report (Nossa Familia Coffee 2019), the company reported a year-over-year reduction in the consumption of single-use cups from 66 to $31 \%$, while $17 \%$ of its costumers brought their own cups. Blue Bottle Coffee, owned by Nestlé, has also piloted a zero-waste coffeehouse in the San Francisco Bay area (CA, USA) by offering to its customers to bring their own cups or rent one from the café, targeting to convert all of their coffeehouses to zero-waste by the end of 2020, diverting $90 \%$ of its waste from landfills. Here Please, an Oakland, California-based (USA) nonprofit, helps cafés and restaurants reduce single-use plastics, promotes the use of reusable cups by training baristas, and educates customers face-to-face using social media and providing visual reminders. In 2019, it helped the Perch Coffeehouse to become the first disposable-fee café in the city, offering a 25-cent discount to costumers bringing their own coffee cup or charging a small fee for renting out a reusable cup or mason jar. Similarly, the city of Freiburg, Germany, has been providing citizens with an easy reusable cup system, a hard-plastic $\mathrm{OOH}$ cup with a disposable lid that customers can obtain with a $€ 1$ deposit and return to any one of the 100 participating businesses across the city. Muuse is another smart system for reusable coffee cups. Originally, Muuse partnered with selected cafes and beverage outlets, in Singapore, San Francisco, and Hong Kong, to switch from single-use to reusable cups stainless steel cups. Hence, the consumer paid a small deposit, which he/she collected when returning the cup. Now, customers using a phone app can pick up cups embedded with a QR code and keep on reusing them for up to 5 days, then returning them to the cafes or a smart return bin. However, market research by Mintel has 
shown that, while consumers show off great environmental intentions, they are often time pressured and price sensitive (ProCarton 2019). The hassle factor of carrying around a reusable coffee cup can limit the popularity of schemes that reward people for doing so. Shaming is another trend for the unconvincing consumers. Photos of scowling Greta Thunberg, the teen climate change activist, next to institutional and office coffee stations has effectively dramatized choosing disposable cups. Finally, consideration must be given to that reusable cups still utilize resources and energy to produce them and therefore have an environmental impact.

Recovery and recycling of used coffee cups is technically feasible and may be economically viable in some cases. It is a feasible and practical approach to handling large volumes of waste single-use cups. Collection, sorting, and processing facilities worldwide are continuing to expand. Successful implementation includes dedicated schemes for collection and collaborations between manufacturers or converters of cups and brand owners or main venue operators. Examples include the recent announcement by Lavazza Professional that their KLIX Eco Cup ${ }^{\mathrm{TM}}$ in its KLIX $^{\circledR}$ in-cup vending machines will be Kotkamills' eco-friendly ISLA ${ }^{\circledR}$ cup, and replacement of single-use cups in Norwich City Football Club's stadium in England starting next season. Similar initiatives have been established in soccer stadiums and concert halls across Germany and other EU countries.

\section{CHALLENGES TO RECYCLING}

Paper is the most recycled municipal and commercial solid waste material, including that found in nondurable goods, such as coffee cups (US EPA 2017). However, with regards to paper cups, the reality is that the majority of waste coffee cups are being sent to landfills or incinerated in spite of the best intentions of brand owners and consumers to promote recycling (Garrison et al. 2016). Traditional cups with PE liners are impervious to microbial action in a composting system and are not biodegradable. While paper is consumed by composting microorganisms, PE becomes brittle over time, separating into microscopic lightweight fragments, which can be readily transported through the ecosystem and create environmental and health problems (Narayan 2011).

Paper cups with PE coatings are recyclable. The challenge is that in many areas the infrastructure needed is not in place. Key elements for successful recycling include (Mouw et al. 2020):

(a) separation and processing of the waste,

(b) reclaiming of fibrous materials - not all recyclers take all packaging,

(c) consistent supply of coffee cups at MRF,

(d) recycling process optimization based on processing coffee cups waste, and

(e) the cost of virgin $v s$. recycled fiber.

When PE-coated paper enters a conventional paper recycling facility, it generally results in operational problems and added cost to the papermaker. During re-pulping, the plastic layer is broken down into flakes, which tend to clog the fine screens separating recyclable fibers from contaminants. Material that does make it through the screens will typically melt out on hot rolls during paper manufacturing. These stickies can cause paper breaks on the papermachine resulting in downtime and production losses. 
Separation of the plastic component coating from the fibrous cupstock can be done effectively. For example, a pilot program spearheaded by Starbucks in 2018 dismissed the myth that PE coffee cups cannot be recycled along with other papers (Peters 2018). In the cup-to-cup closed loop partnership project, fibers were successfully separated from coffee cups and re-pulped to make recycled market pulp at the Sustana pulpmill in Wisconsin (USA). The recovered fiber pulp was then used by WestRock to produce cupstock, which was subsequently converted to new coffee cups by Seda Packaging. Sustana reported that (a) the fiber quality was superior to that recovered from other packaging, such as milk cartons, and (b) it was not more expensive to separate PE from coffee cups than from other fibrous-based packaging (Peters 2018). Currently, Sustana offers its EnviroLife ${ }^{\mathrm{TM}}$ pulp from $100 \%$ post-consumer recycled fiber to FDA-compliant packaging with direct food contact. Many brands of cupstock paperboard in the USA now contain over $30 \%$ recycled fiber from post-consumer waste. An example is the Nuvo ${ }^{\circledR}$ cupstock offered by Clearwater Paper, based on multi-ply fiber blending with up to 35\% post-consumer fiber from Sustana.

Recycling of used coffee cups is technically and economically feasible. However, it requires a concerted effort of the whole supply chain. Continued success in recycling coffee cups depends on a consistent supply stream of used coffee cups so that a recycle pulp mill can continually operate efficiently under optimized conditions to process recovered cups. Not all communities and municipalities accept wasted coffee cups. Broadly, local or regional recyclers have been unwilling to take cups - something that at present is limited in most countries.

Efforts in developed economies during the past two years have shown promise in systematically collecting, sorting, and processing used coffee cups. Led by San Francisco, other cities like Seattle, New York, Washington D.C., and Denver have implemented coffee cup collection, separation, and sorting processes to send substantial cup volumes into recycled pulp mills, such as Sustana. Recyclers started including clean coffee cups in their bales, which then can be easily accepted by a recycling pulpmill with the rest of the papers. An example is the commitment to accept paper coffee cups by Recology, a major recycler headquartered in San Francisco that provides collection, recyclables sorting, marketing, composting, and landfilling services to communities in California, Oregon, and Washington. In contrast, efforts by industrial groups like the Foodservice Packaging Initiative (FPI) in the USA aim to expand recycling through its Paper Recovery Alliance. In Europe, recycling is mostly driven by policy, including incentives for investment in recycling infrastructure. In the UK, for instance, according to the PCRRG, residential recycling schemes and four large reprocessing plants enabled the levels of coffee cup recycling to be raised from 1:400 in 2017 to 1:25 in 2018, reaching 1:12 in 2019 (Reed 2018). Programs such as the Simple Cups in the UK and the Close Loop in Australia have facilitated collecting and recycling paper coffee cups. Brands, such as McDonald's and Costa Coffee, have installed collection bins specifically for coffee cups in their UK stores.

Recycling Service, UK, makes it easy to recycle paper coffee cups, by collecting waste cups directly from retail outlets. CupCycling ${ }^{\mathrm{TM}}$ by James Cropper, UK, is another example of a collaborative recycling scheme, involving supply chain and brand owners, dedicated to upcycling $\mathrm{OOH}$ paper coffee cups to tailor-made papers. In contrast, in Japan, there is already an established practice to collect and recycle PE-coated packaging, separating, and incinerating the plastic component.

One example of how coffee cups can be successfully integrated within a recycling program is given by Smart Planet Technologies (US). It recently commercialized reCUPTM (also under Vericup ${ }^{\mathrm{TM}}$ in the UK), a paper cup designed with a minimal plastic (resin) 
content and an inner liner that is re-pulpable. Their EarthCoating ${ }^{\circledR}$ barrier technology is a blend of calcium carbonate mineral and polyolefinic resins, like PE, which can be applied with existing coating equipment while the wasted cup is readily recyclable. These barrier cups contain 41 to $50 \%$ less plastic than cups made from 100\% fossil-based PE liner. Another example is converter Beautiful Cups (The Netherlands), which collaborates with Renewi, a waste management and recycling company, to offer a closed loop solution. Beautiful Cups, made with $95 \%$ fiber and 5\% plastic, are collected in special bags and Renewi upcycles them into toilet paper, while the plastic component of the cups is also recycled. This project has been rolled out in 10 countries so far. In mid-2018, Pacific City, CA (USA) showcased reCUPTM products during the US Open of Surfing, along with a closed-loop recycling program for reCUP ${ }^{\mathrm{TM}}$ paper cups. This initiative is considered to be a blueprint for addressing paper cup waste at the municipal level, creating an environmentally sustainable approach to paper cup use. Such programs can become enablers, not only in separate cup recycling, but also in adopting new sustainable paper cups and foodservice packages.

Another approach is to make recycling easy. FrugalCup TM from startup Frugalpac (UK) is a composite paper cup that can be disposed in any recycling bin and recycled with any mainstream waste process (Frugal Cup 2020). It comprises two individual cup components: an outer made from recycled paperboard, an inner made from food-grade PE. Each component easily separates in the re-pulper during recycling, so that the fiber can be recycled again, while the inner plastic liner can be separately recycled or incinerated. The Frugal Cup Linerless ${ }^{\mathrm{TM}}$ is manufactured from sustainable virgin paperboard, treated with a proprietary coating for paper cup recycling. A Frugal Lid is also made from molded fibrous pulp out of sugarcane waste. Both Frugal cups and lids can be readily disposed in any recycling bin, collected, separated, and processed to make more cups without changing the recycling processes.

Major recycled paperboard manufacturers have been at the scale-up and commercialization stages to implement paper mill technologies to handle foodservice waste, including single-use $\mathrm{OOH}$ paper coffee cups. Noteworthy is the Advanced Foodservices Packaging Recycling project spearheaded by WestRock. Through optimization in pulping and cleaning systems, the company's mills are able to handle foodservice packaging, including used coffee cups. Proven on a pilot program in a couple of their mills, bails from foodservice packaging are now accepted in seven of the company's recycled paperboard mills. A similar project is pursued by Georgia-Pacific based on its patented Juno ${ }^{\mathrm{TM}}$ process. By applying heat and pressure to foodservice packaging, the materials can be screened and separated into fiber, plastic, and metal streams. Recovered fiber is then mixed in with old corrugated container (OCC) pulp and processed to make new packaging materials.

Collection, sorting, and processing facilities worldwide are continuing to expand. However, several challenges remain, including inconsistencies in waste collection service models, policy patchworks, market access to consistent volumes of clean cups, and infrastructure investments made for recycling. Additionally, biodegradable coffee cups are not the best for composting facilities; some of them do not even accept them because they contaminate their composting streams as consumers typically discard them with look-alike non-compostable cups (Wozniacka 2020). 


\section{CURRENT STATE OF COMMERCIAL TECHNOLOGIES DESIGNED TO REPLACE PE LINERS}

Responding to customer sentiment and the drive of brand owners for sustainable packaging, papermakers and converters have introduced a range of sustainable cupstock solutions, including cups that are repulpable when processed in recycled fiber papermills or even compostable in industrial sites. Efforts have been made to incorporate increased renewable components into cupstocks and replace the fossil-based PE barrier layer. Replacements of the paper coffee cup liner include bio-based plastics, processed in existing extruders or water-based dispersions that are either extruded or applied onto cupstock paperboard on existing coaters. Worth noting is the fact that polymers made from bio-based feedstocks are not necessarily always biodegradable. With regards to paperboard processing costs, new coating processes, such as online extrusion, slot, and slide curtain coaters, have a real potential to lower unit cupstock costs by eliminating the need for offline handling, extrusion, or lamination. As a reference, Table 1 lists current and emerging manufacturers and converters of sustainable paper coffee cups.

Table 1. Sustainable Paper Coffee (Hot) Cups and Materials (Manufacturers, converters)

\begin{tabular}{|c|c|c|c|}
\hline Product & $\begin{array}{c}\text { Manufacturer } \\
\text { (Country) }\end{array}$ & Technology & Sustainability Claim(s) \\
\hline $\begin{array}{c}\text { Acrycote resins } \\
\text { (cup liners) }\end{array}$ & APEC (KR) & $\begin{array}{l}\text { Acrylate water- } \\
\text { based coating }\end{array}$ & Recyclable \\
\hline $\begin{array}{c}\text { Bare } \\
\text { (solo eco-forward) }\end{array}$ & $\begin{array}{l}\text { Dart Container } \\
\text { Corporation (US) }\end{array}$ & PLA & Compostable \\
\hline Bioastra cups & Bioastra (CA) & $\begin{array}{l}\text { Polymer-based } \\
\text { phase-changing } \\
\text { nano-emulsions }\end{array}$ & $\begin{array}{c}\text { Recyclable, } \\
\text { biodegradable }\end{array}$ \\
\hline BioBarrier coating & Colombier (NL, FI) & Water-based coating & Recyclable \\
\hline BioChoice cups & Cape Cup (SA) & $\begin{array}{c}\text { Kraft of bamboo } \\
\text { paper with PLA, } \\
\text { single/double wall }\end{array}$ & Compostable \\
\hline Bio Paper cups & DoECO (RU) & $\begin{array}{c}\text { Kraft paper with } \\
\text { PLA, single/double } \\
\text { wall }\end{array}$ & Recyclable, compostable \\
\hline Bioware cups & Huhtamaki (FI) & PLA & Compostable \\
\hline Bridge-Gate cups & $\begin{array}{c}\text { Bridge-Gate Alliance } \\
\text { Group (US) }\end{array}$ & PLA & Compostable \\
\hline Butterfly cups & Hanpak (IRL) & PBS & Recyclable, compostable \\
\hline Coffee cups & $\begin{array}{l}\text { Barriertec Packaging } \\
\text { \& Groupe Research } \\
\text { I.D. Inc. (CA) }\end{array}$ & $\begin{array}{c}\text { Polymeric } \\
\text { combination of } \\
\text { selected salts, } \\
\text { calcite or polyvinyl } \\
\text { alcohol, latexes, } \\
\text { fatty acids }\end{array}$ & Repulpable \\
\hline Coffee cups & $\begin{array}{c}\text { Minima Technology } \\
\text { (TW) }\end{array}$ & PLA, bioPBS & Compostable \\
\hline Coffee cups & $\begin{array}{c}\text { Nanjing Anbao } \\
\text { Paper Products }(\mathrm{CH})\end{array}$ & PLA, bioPBS & Compostable \\
\hline
\end{tabular}




\begin{tabular}{|c|c|c|c|}
\hline Product & $\begin{array}{c}\text { Manufacturer } \\
\text { (Country) }\end{array}$ & Technology & Sustainability Claim(s) \\
\hline Coffee cups & $\begin{array}{l}\text { President Packaging } \\
\text { (TW) }\end{array}$ & PLA & Compostable \\
\hline Coffee cups & $\begin{array}{c}\text { Sans Packaging } \\
(\mathrm{CH})\end{array}$ & PLA & Compostable \\
\hline $\begin{array}{c}\text { Compostable paper } \\
\text { (hot cup) }\end{array}$ & Pactiv (US) & PLA & Compostable \\
\hline $\begin{array}{c}\text { Cupforma Natura } \\
\text { cupstock }\end{array}$ & Stora Enso (FI) & PLA & Compostable \\
\hline $\begin{array}{l}\text { Dixie Ultra Insulair } \\
\text { (double-wall cup) }\end{array}$ & Georgia Pacific (US) & $\begin{array}{l}\text { PE liner with a heat- } \\
\text { activated internal air } \\
\text { pocket }\end{array}$ & Recyclable \\
\hline Earth cup & $\begin{array}{l}\text { Biodegradable Earth } \\
\text { Service (US) }\end{array}$ & PLA & Compostable \\
\hline Earth cup & $\begin{array}{l}\text { Biodegradable Food } \\
\text { Service (US) }\end{array}$ & PLA & Compostable \\
\hline Earth cup & $\begin{array}{c}\text { Europeene des } \\
\text { Emballages (FR) }\end{array}$ & Paper monomaterial & Compostable \\
\hline $\begin{array}{c}\text { Eco-barrier Prime FBB } \\
\text { EB cupstock }\end{array}$ & MetsäBoard (SE) & Water-based coating & $\begin{array}{c}\text { Recyclable, } \\
\text { biodegradable }\end{array}$ \\
\hline Econtainer cups & $\begin{array}{c}\text { Graphic Packaging } \\
\text { (US) }\end{array}$ & PLA & Compostable \\
\hline EcoCup & EcoPack (SA) & $\begin{array}{l}\text { PLA, single/double } \\
\text { wall }\end{array}$ & Recyclable, compostable \\
\hline Evolution World cups & ECO Products (US) & $\begin{array}{c}\text { PE with } 24 \% \text { post- } \\
\text { consumer fiber } \\
\text { content }\end{array}$ & Recyclable \\
\hline $\begin{array}{l}\text { Extraordinary } \\
\text { (paper cup) }\end{array}$ & Petra International & $\begin{array}{c}\text { Paper with a } \\
\text { penetrating } \\
\text { treatment }\end{array}$ & Recyclable, compostable \\
\hline Foldable "all in one" cup & All in One & & Recyclable \\
\hline $\begin{array}{c}\text { Foodpak } \\
\text { BioNatura cups } \\
\end{array}$ & $\begin{array}{c}\text { Asia Pulp \& Paper } \\
\text { (ID) }\end{array}$ & $\begin{array}{c}\text { Water-based } \\
\text { dispersion }\end{array}$ & Recyclable, compostable \\
\hline $\begin{array}{c}\text { Footprint } \\
\text { (cups and lids) }\end{array}$ & Footprint (US) & $\begin{array}{l}\text { Molded fiber lids and } \\
\text { water-based coating }\end{array}$ & Recyclable, compostable \\
\hline FrugalCup & Frugalpac (UK) & PE & Recyclable \\
\hline FrugalCup Linerless & Frugalpac (UK) & Proprietary coating & Recyclable \\
\hline G2 cups & $\begin{array}{c}\text { Team Three Group } \\
\text { (US) }\end{array}$ & PLA & Compostable \\
\hline Grasspaper cups & Crearpaper (GE) & $\begin{array}{l}\text { Grass-based fibrous } \\
\text { cups }\end{array}$ & Recyclable, compostable \\
\hline Greenstripe cups & ECO Products (US) & PLA & Compostable \\
\hline $\begin{array}{l}\text { Greenus } \\
\text { (hot cup) }\end{array}$ & $\begin{array}{c}\text { Hanchang Paper } \\
\text { (KR) }\end{array}$ & PLA, sugarcane & Compostable \\
\hline $\begin{array}{l}\text { Insulated Hold\&Go } \\
\text { (hot cups) }\end{array}$ & $\begin{array}{c}\text { Graphic Packaging } \\
\text { (US) }\end{array}$ & $\begin{array}{c}\text { Double wall cups } \\
\text { with Thermashield } \\
\text { air gap, } \mathrm{PE} \text { liner, } 10 \\
\text { to } 40 \% \text { post- } \\
\text { consumer fiber } \\
\text { content } \\
\end{array}$ & Recyclable \\
\hline
\end{tabular}




\begin{tabular}{|c|c|c|c|}
\hline Product & $\begin{array}{c}\text { Manufacturer } \\
\text { (Country) }\end{array}$ & Technology & Sustainability Claim(s) \\
\hline $\begin{array}{c}\text { Invercote GP and } \\
\text { Incada Exel } \\
\text { (paperboard) }\end{array}$ & $\begin{array}{l}\text { Iggesund Holmen } \\
\text { (SE) }\end{array}$ & PE & Recyclable \\
\hline ISLA cups & Kotkamills (FI) & $\begin{array}{l}\text { Multilayered water- } \\
\text { based dispersions }\end{array}$ & Recyclable, compostable \\
\hline Karat Earth cups & Lollicup (US) & PLA & Compostable \\
\hline Lush packaging cups & $\begin{array}{l}\text { Anqing Lush Paper } \\
\text { Industry }(\mathrm{CH})\end{array}$ & PLA & Compostable \\
\hline Mushroom cups & Concentric (US) & $\begin{array}{c}\text { Liner with } \\
\text { agricultural waste } \\
\text { bound by dormant } \\
\text { Mycelium fungi in a } \\
\text { cellulose acetate } \\
\text { coating }\end{array}$ & Biodegradable \\
\hline Nanocellulose coating & $\begin{array}{l}\text { Innotech Materials } \\
\text { (US) }\end{array}$ & $\begin{array}{l}\text { Hydrophobic ethyl } \\
\text { nanocellulose liquid } \\
\text { crystalline liners }\end{array}$ & Biodegradable \\
\hline Natura Sanitas & INDEVCO (LB) & $\begin{array}{l}\text { Water-based } \\
\text { emulsion coating }\end{array}$ & Recyclable \\
\hline Naturally Seda & Seda (US) & PLA & Compostable \\
\hline Nature cup & $\begin{array}{c}\text { GreenCentury } \\
\text { Enterprises (CA) }\end{array}$ & PLA & Compostable \\
\hline Nature's cup & Crème & $\begin{array}{c}\text { Naturally grown } \\
\text { cups inside custom- } \\
\text { designed 3D-printed } \\
\text { molds } \\
\end{array}$ & $\begin{array}{l}\text { Biodegradable, } \\
\text { compostable }\end{array}$ \\
\hline Natures cup & Natures Cup (UK) & $\begin{array}{l}\text { Double-wall cup with } \\
\text { air gap and PLA }\end{array}$ & Compostable \\
\hline $\begin{array}{c}\text { NewGen BioPBS resins } \\
\text { for cup liners }\end{array}$ & $\begin{array}{l}\text { PTT MCC Biochem } \\
\text { (IN) }\end{array}$ & PBS & Recyclable, compostable \\
\hline Nuvo cupstock & $\begin{array}{c}\text { Clearwater Paper } \\
\text { (US) }\end{array}$ & PE & Recyclable \\
\hline OmegaBev & Natur-Tec (US) & $\begin{array}{l}\text { PLA, synthetic resin- } \\
\text { polydimethylsiloxane } \\
\text { coating }\end{array}$ & Compostable \\
\hline Pando cups & $\begin{array}{l}\text { Zhejiang Pando EP } \\
\text { Technology }(\mathrm{CH}) \\
\end{array}$ & PLA & Compostable \\
\hline Paper cup & $\begin{array}{c}\text { Totempak Solutions } \\
\text { (TW) }\end{array}$ & PLA & Compostable \\
\hline Pland paper cup & $\begin{array}{c}\text { Xiamen Wei Mon } \\
\text { Environmental } \\
\text { Materials }(\mathrm{CH})\end{array}$ & PLA & Compostable \\
\hline PLAP cups & Mei Mon (TW) & PLA & Compostable \\
\hline PrimeWare cups & $\begin{array}{c}\text { AmerCareRoyal } \\
\text { (US) }\end{array}$ & PLA & Compostable \\
\hline $\begin{array}{l}\text { reCUP } \\
\text { Vericup } \\
\end{array}$ & $\begin{array}{c}\text { Smart Planet } \\
\text { Technologies (US) }\end{array}$ & $\begin{array}{c}51 \% \mathrm{CaCO}_{3}, 49 \% \\
\text { LDPE coating }\end{array}$ & Recyclable \\
\hline rePaper cups & rePaper (KR) & $\begin{array}{l}\text { Acrylate water- } \\
\text { based coating }\end{array}$ & Recyclable \\
\hline
\end{tabular}




\begin{tabular}{|c|c|c|c|}
\hline Product & $\begin{array}{c}\text { Manufacturer } \\
\text { (Country) }\end{array}$ & Technology & Sustainability Claim(s) \\
\hline $\begin{array}{l}\text { Restoration packaging } \\
\text { cups } \\
\end{array}$ & $\begin{array}{c}\text { Restoration } \\
\text { Packaging (US) }\end{array}$ & PLA & Compostable \\
\hline $\begin{array}{c}\text { Sentinel } \\
\text { (cupstock) }\end{array}$ & $\begin{array}{c}\text { Evergreen } \\
\text { Packaging (US) }\end{array}$ & Green PE & Recyclable \\
\hline SGMA ZP2C & $\begin{array}{c}\text { Solgel Advanced } \\
\text { Materials (UK) }\end{array}$ & $\begin{array}{l}\text { Sol-gel barrier } \\
\text { coating }\end{array}$ & Biodegradable \\
\hline $\begin{array}{l}\text { Single and double wall } \\
\text { hot cups }\end{array}$ & $\begin{array}{l}\text { Hefei Hengxin Env } \\
\text { Sci Techn }(\mathrm{CH})\end{array}$ & PLA & Compostable \\
\hline $\begin{array}{c}\text { Solo } \\
\text { (hot cups) }\end{array}$ & $\begin{array}{l}\text { Dart Container } \\
\text { Corporation (US) }\end{array}$ & PE & Recyclable \\
\hline Stalkmarket cups & Seda (US) & $\begin{array}{c}\text { Molded cellulosic } \\
\text { fiber }\end{array}$ & Compostable \\
\hline $\begin{array}{l}\text { Sustainex } \\
\text { (cupstock) } \\
\end{array}$ & Mondi (AT) & PLA & Compostable \\
\hline $\begin{array}{c}\text { Thermolite } \\
\text { (double-wall cups) }\end{array}$ & $\begin{array}{l}\text { LBP Engineering } \\
(\mathrm{US})\end{array}$ & $\begin{array}{l}\text { PE and synthetic air } \\
\text { lattice between walls }\end{array}$ & Recyclable \\
\hline TopScreen coatings & Solenis (US) & $\begin{array}{c}\text { Polystyrene } \\
\text { maleimide with } \\
\text { vegetable oil } \\
\text { coatings with/without } \\
\text { pigments }\end{array}$ & Recyclable, compostable \\
\hline TruServ & WestRock (US) & PLA & Compostable \\
\hline Unocup cup & Unocup (US) & $\begin{array}{l}\text { Foldable paper with } \\
\text { PE barrier (no lids) }\end{array}$ & Recyclable \\
\hline Vegware cups & Vegware (US) & PLA & Compostable \\
\hline Viaggio cups & Seda (US) & Double wall with $\mathrm{PE}$ & Recyclable \\
\hline Vista cups & $\begin{array}{c}\text { GreenCentury } \\
\text { Enterprises (CA) }\end{array}$ & PE & Recyclable \\
\hline Walki cups & Walki (FI) & Green PE & Recyclable \\
\hline World Art cups & ECO Products (US) & PLA & Compostable \\
\hline $\begin{array}{c}\text { World Art } \\
\text { (insulated cups) }\end{array}$ & ECO Products (US) & PLA, double wall & Compostable \\
\hline World Centric cups & World Centric (US) & PLA & Compostable \\
\hline YJS cups & $\begin{array}{l}\text { YJS Environmental } \\
\text { Solutions (TW) }\end{array}$ & PLA & Compostable \\
\hline
\end{tabular}

\section{Green Polyethylene}

Of the many available options, Sentinel ${ }^{\mathrm{TM}}$ is a renewable cupstock produced by Evergreen Packaging. The product claims to be made from $97 \%$ biobased ingredients, with $10 \%$ of the PE layer derived from sugarcane to lower the overall carbon footprint of the product. It is offered in one-side PE coated paperboard for hot coffee cupstock with features that ease converting and printability. The cupstock uses a PE called green ${ }^{\mathrm{TM}}$ Polyethylene, supplied by Braskem (São Paulo, Brazil), which is produced from bio-based ethanol made from sugarcane grown under sustainable standards. It has the same chemical signature as 
fossil-based PE. While it is recyclable, it is not biodegradable or compostable. Moreover, it is unclear whether a bio-based PE has any real environmental benefits.

\section{Water-based Dispersion Coatings}

Attempts have been made, with some economically commercial success, to use water-based emulsions and/or pigmented coatings for the production of recyclable and compostable coffee cups. Water-based barrier coatings (WBBC) containing polymer dispersions are formulated with water-based resin (latex) emulsions containing 40 to $50 \%$ colloidal polymeric particles, along with other additives, such as dispersants, thickeners, wetting surfactants, and/or mineral pigments. Additives and inorganic pigments (type and addition levels) can improve barrier performance, but these can also create crack-at-thefold problems (Vähä-Nissi et al. 2001). Typical dispersion resins are pure acrylic polymers, copolymers of acrylates such as ethyl acid acrylates and ethylene methacrylate, polyvinyl acetates, styrene butadiene copolymers, and polyolefins. Sometimes, different polymers are blended or applied in multiple layers to provide the required performance.

Water-based barrier coatings are applied onto cupstocks on both the sidewall and bottom of a cup, and they can be single or multiple coatings. Upon drying, a water-based polymeric emulsion forms a barrier thermoplastic film that provides the required resistance to water, hot liquids, and fatty acids. In contrast to paper coatings for printing, barrier coatings are formulated below the critical pigment volume concentration when pigment is used, so that a continuous polymeric film covers the entire paperboard surface. Waterbased polymers for barrier coatings represent $36 \%$ of the paper and paperboard barrier market (Crowther-Alwyn 2019). To achieve barrier properties for coffee cups, multiple WBBC coating layers are required, typically applied by rod, roll, filmpress, curtain, blade, or reverse gravure coaters.

There are several requirements to meet for successful implementation of WBBC and latex-based technologies to barrier coatings. In addition to water vapor, oil, and fatty acids resistance, a coated cupstock needs to show:

- no blocking during converting to cups;

- heat sealing at 300+ cups/min cup converting machines;

- flexural strength to avoid cracks at a fold;

- retention of cup sidewall stiffness upon exposure to hot liquids up to $100{ }^{\circ} \mathrm{C}$; and

- resistance to coffee cup edge wicking.

Barrier performance requires wetting of the coating onto the base paperboard substrate to achieve good adhesion, especially on heavily sized paperboards, and uniformly continuous substrate coverage. Cupstock paperboard quality, smoothness, and coating layer uniformity are important aspects for a successful barrier function. The coating layer must also be free of pinholes that adversely affect the barrier function. Pinholes from foam or air bubbles generated during coating preparation and processing can be eliminated by using best practices for coating make-down and delivery. Intense, fast drying of the applied coating film may also create bubbles that form pinholes upon bursting and allow liquids to go through the final barrier coating. While resisting hot liquids, the coated cupstock also needs to have no odor and not create an aftertaste upon its use with a hot beverage, while complying with national and international regulatory food contact requirements. 
Being able to pass all the above requirements simultaneously has proven to be a challenge for cupstocks with water-based emulsions and coatings. Thermoplastic latexes create strong, flexible films that are good for cup strength and hot melt sealability. However, they may also gradually soften and become sticky when at elevated temperatures $\left(\sim 49\right.$ to $\left.55^{\circ} \mathrm{C}\right)$, generating tacky films that create blocking during the converting operation, such as sticking to the mandrills of the cup forming machine. Blocking limits cup forming speed, adversely affecting line productivity. Hot air sealed paper cup machines are competitively run at speeds over 150 cups, preferably over 300 cups, per minute, which makes it challenging to meet anti-blocking and heat sealability requirements. Many times, formulation strategies are competing against each other. Although mineralization of a water-based formulation helps resistance to blocking, cracks may develop at the fold when attaching the side wall to the bottom of the cup. Therefore, formulating for resistance to blocking, while preserving sealability, is a critical step in successful application of WBBC. Thermoplastic coating films with $100 \%$ latex emulsions are based on pure acrylics or acrylate copolymers, typically formulated with dispersants, thickeners, wetting aids, and other additives for processability during coating and converting. These coatings also require FDA/BfR compliance for food contact, FBA or equivalent certificates for recyclability, and/or qualifications of DIN EN 13432:2000 (2007), preferably compostable product certification from the Biodegradable Products Institute (BPI).

Recently commercialized, paper cups coated with latex or WBBC are generally recyclable, re-pulpable, and even compostable in industrial facilities (Ju et al. 2017; Hämäläinen 2019). Coatings based on pure acrylics and acrylate copolymers have been successfully used to make coffee cups in several regions around the world. Among others, examples are: acrylates from Advanced Polymer Emulsions Company (APEC), Korea, and BASF (Germany); ethyl acid acrylate (EAA) copolymers from SK Chemical (Korea); commercial ready-to-use coating formulations such as VaporCoat ${ }^{\circledR}$ and Michem ${ }^{\circledR} \mathrm{Coat}$ from Michelman (USA); REPA ${ }^{\circledR}$ coatings by rePaper (Korea); or CHP BAR ${ }^{\circledR}$ coatings with mineral pigments from $\mathrm{CH}$-Polymers (Finland). On the pigment side, Imerys offers Barrisurf $^{\mathrm{TM}} \mathrm{HX}$, a coarse hyper-platy clay that imparts barrier and hydrocarbon resistant performance in WBBC. Imerys also provides formulated coatings with their Century ${ }^{\mathrm{TM}}$ delaminated kaolin, Steaplus ${ }^{\circledR}$ Prime minerals, and Barrikote ${ }^{\mathrm{TM}}$ formulations. Based on platy minerals and specialty polymers, Barrikote ${ }^{\mathrm{TM}}$ coatings are claimed to provide equivalent water resistance, heat sealability, anti-blocking, and crack-resistance as traditional PE liners at $70 \%$ thinner film thickness with the added bonus of recyclability (De Sailly 2018). Specific coatings have been developed for multilayered curtain coating, while formulation design includes choice of the appropriate polymer. Ethyl acid acrylate emulsion polymers in WBBC demonstrate comparatively better barrier properties with sealability and blocking resistance, while other acrylate copolymers give a thin balance of properties because optimization of their polymeric design for one property adversely affects another.

Typically, water-based polymer dispersions are formulated into ready-to-use coatings for cupstock. An example is the ACRYCOTE ${ }^{\circledR}$ APC-200 resin by APEC. It is based on acrylate-carboxylic acid copolymers, which are polymerized at the presence of a reactive emulsifier and a multifunctional silicone polymer (Shim 2016). These acrylate emulsions exhibit low volatile organic compound (VOC) emissions and are formulated to environmentally preferred WBBC for $\mathrm{OOH}$ paper coffee cup recycling or composting in industrial facilities. Coat weights of 8 to $10 \mathrm{~g} / \mathrm{m}^{2}$ have been applied on paperboard with gravure coaters to create 150 to $350 \mathrm{~g} / \mathrm{m}^{2}$ cupstocks, which impart good sealability, and 
comparable physical, water, and oil resistance properties to PE coatings. More recent variations incorporate a 3 to $10 \mathrm{~g} / \mathrm{m}^{2}$ precoating, with 6 to $12 \mathrm{~g} / \mathrm{m}^{2}$ top coating, onto 150 to $350 \mathrm{~g} / \mathrm{m}^{2}$ base board (Larsson and Emilsson 2019). BASF also offers developmental acrylate water-based polymers that provide heat-sealable, block-resistant, and liquid barrier coatings, making paper coffee cups re-pulpable. In some cases, there is a combination of PE liner with an aqueous water-based dispersion coating. These new polymer systems are at the pilot scale and machine trial stages. While multiple development efforts are in progress, consistently passing all cupstock barrier and converting performance requirements simultaneously has been proven difficult for emulsions.

Another example of water-based coatings is REPA ${ }^{\circledR}$ Coat, an acrylate-based emulsion resin by RePaper. A recent patent discloses emulsion polymer resins synthesized with copolymerized acrylate monomers and cyclosiloxanes to form a copolymer having 100,000 to 200,000 molecular weight. The polymer is blended with up to $15 \%$ gelatinized polyvinyl alcohol to form the emulsion copolymer (Yoon 2019). These copolymers are formulated into WBBC REPA ${ }^{\circledR}$ coatings, which are applied onto the side wall to provide desired barrier properties, namely, Cobb, water-vapor transmission rate (WVTR), and oil and grease resistance (OGR). The coatings are said to provide good sealability and improved blocking performance over pure thermoplastic films. Typically, a single coating layer of 8 to $10 \mathrm{~g} / \mathrm{m}^{2}$ is sufficient to provide barrier properties on a 200 to $350 \mathrm{~g} / \mathrm{m}^{2}$ paperboard for paper coffee cups. The coating thickness is half or two-thirds lower than that required with PE films. Re-pulpability yield of rePaper beverage cups coated with REPA $^{\circledR}$ has been better than that of those coated with PE or PLA (Ju 2017). Additionally, cups with REPA $^{\circledR}$ coatings are compostable in industrial facilities. Commissioned studies under controlled composting conditions $\left(58{ }^{\circ} \mathrm{C}, 48\right.$ days) demonstrated greater than $90 \%$ average biodegradation. However, their widespread adoption is hindered by blocking problems during converting in cup machines at speeds over $300 \mathrm{cups} / \mathrm{min}$, which can adversely affect productivity.

CHP BAR ${ }^{\circledR}$ coatings by CH-Polymers (Finland) are also based on acrylate chemistry. These have been used to formulate pigmented coatings for cupstock that are recyclable and biodegradable in industrial composting facilities. These WBBCs give good grease and mineral oil barrier properties and can be designed to also provide moisture and water resistance. Similarly, Charta Global, in a strategic partnership with Asia Pulp \& Paper, has introduced their Foodpak Bio Natura Cup ${ }^{\mathrm{TM}}$, which is based on an aqueous dispersion coating (Lingle 2018). The product is said to provide hot liquid holdout with good sealing properties. It complies with FDA requirements for food contact, as well as with the FTC's Green Guides for biodegradability and compostability.

Different types of water-based chemistries have also been used to replace PE liners and create commercially feasible barrier coatings. Examples include technologies commercialized by Footprint and Colombier. Footprint, a sustainable packaging company from Arizona (USA), has also created water-based barrier coatings to make recyclable and compostable fiber-based coffee cups. Water repellency is created by combining alkyl ketene dimer (AKD) sizing agent with polyamide epichlorohydrin (PAE), starch, and inorganic salts (Chung et al. 2018). Colombier, from The Netherlands and Finland, has introduced the BioBarrier ${ }^{\circledR}$ coatings that are tailor made for specific product applications, including paper coffee cups, to impart selected properties such as water, water vapor, oil and grease, and heat resistance. In this case, the barrier coating forms a monomaterial together with the coated base material, while a separate coating on the outside wall of a 
cup provides optical and appearance properties. Cups with BioBarriers are recyclable and compostable.

Other water-based products at the early commercialization stage show promise for application to paper coffee cups. Dow Coating Materials offers RHOBARR ${ }^{\text {TM }}$ 320, a polyolefin dispersion (POD) that meets barrier performance requirements for hot beverages cupstock (Piwowar et al. 2019). The particular PODs contain the base resin and additives for processing, adhesion, and wetting in existing extruders. To achieve acceptable barrier performance, their application requires less raw material than with conventional fossilbased resins, comparatively 10 to $15 \%$ lower weight. This reduces waste and enables almost complete (99\%) fiber recovery from recovered waste cups. Under license, Paramelt (USA) developed commercial capability to produce mechanical dispersions (Aquaseal ${ }^{\mathrm{TM}}$ ) of high-molecular weight thermoplastic polyolefins and styrene block copolymers in water, which is based on Dow's proprietary Bluewave ${ }^{\mathrm{TM}}$ technology; this enables dispersion of polymers that are not self-dispersing (Rao 2009).

Yet another type of aqueous coating formulation with barrier properties has been introduced by TopChim NV (now Solenis). TopScreen ${ }^{\mathrm{TM}}$ technology is based on imidization of polystyrene maleic anhydride (SMA) in the presence of vegetable oil to yield polystyrene maleimide (SMI). This creates water-dispersed particles that incorporate the vegetable oil in a core-shell structure. The particles are 0.1 to 0.15 microns in diameter and contain up to $70 \%$ vegetable oil. TopScreen ${ }^{\mathrm{TM}}$ coatings have been shown to have similar properties to PE-coated paper cups on a lower weight cupstock (Stanssens 2017). They work well as a barrier, either as a standalone layer or as a top coating in multilayered designs. In both cases, the TopScreen ${ }^{\mathrm{TM}}$ coating must sit on top of the paperboard to achieve good sealability. As a result, the type of coating method used and coating viscosity at the sealing temperature will dramatically impact coating performance. Vercammen's (2019) recommendations include using TopScreen ${ }^{\mathrm{TM}} \mathrm{PC}$ at 3 to $10 \mathrm{~g} / \mathrm{m}^{2}$ as a precoating, followed by 6 to $12 \mathrm{~g} / \mathrm{m}^{2}$ of TopScreen ${ }^{\mathrm{TM}} \mathrm{TC}$ for the inner liner barrier layer, and 1 to 3 $\mathrm{g} / \mathrm{m}^{2}$ of outside cupstock coating for sealing and printability. These coatings can be applied with rod, blade, or curtain coaters, and they fit well with operations that can deploy a variety of coating techniques. A recommended application includes multilayering with double coating for the inner wall of a cup, i.e., a liquid repellant/heat sealable top coating added on to a non-water repellant base coating, and separately applying a single coating on the external wall to enhance fiber tear resistance after sealing. Converting to recyclable and potentially compostable cups has been demonstrated at production rates over 300 cups per minute. Recent trials at the UMV pilot facility in Sweden demonstrated successful application with rod, resilient tip, and blade tip on zero and long-dwell coaters of the TopScreen ${ }^{\text {TM }}$ TC372 pigmented coating for cupstock (Hutchinson 2019).

Thermolite ${ }^{\mathrm{TM}}$ insulating technology is yet another option to brand owners and converters. Offered by LBP Manufacturing, a thermally expandable coating is applied onto the cupstock of a double-wall cup in a pattern form, filling the air gap between the two walls (Fu and Cook 2017). This results in a synthetic air lattice structure, which provides thermal insulation, improved mechanical strength, and cup integrity in double-wall cups (Fig. 4). The coating contains expandable microspheres that activate at a temperature around $88{ }^{\circ} \mathrm{C}\left(190{ }^{\circ} \mathrm{F}\right)$ and an adhesive to form, upon expansion, an insulating layer between the two walls that provides insulation by reducing thermal conductivity. The microspheres are expanded during cup manufacturing or during use when hot beverages are added to the cup. The insulation coating with microspheres is formulated from 
renewable materials and applied in-line during converting to create an environmentally preferred coffee cup.

With its Flying Eagle project, Kotkamills has successfully implemented papermaking technology to produce cupstock that eliminates the need for a separate PE barrier liner (Rodden 2018). As an integrated mill, it has the advantage to control basesheet properties, such as formation, sheet porosity, and smoothness for coatweight uniformity, a key variable for optimum barrier performance of a cup. A good example of how to exploit modern coating methods for efficiency is the company's use of an in-line curtain coater to apply two coating layers simultaneously on each side of the web. Multi-layering gives the opportunity to apply different coatings at the same time, e.g., one designed for water vapor transmission resistance and another one selected for oil and grease or fatty acids resistance. Additionally, a metered-size press and a blade coater make it possible to apply up to a total of seven barrier layers online. The capability to manufacture baseboard and coat it online at the same site provides a cost competitive advantage over off-machine coating (Rodden 2018). Besides making the uncoated ISLA ${ }^{\mathrm{TM}}$ Cup Base for traditional coating with an extruder, Kotkamills produces ISLA ${ }^{\text {TM }}$ DUO coated board in weights of 160 to $325 \mathrm{~g} / \mathrm{m}^{2}$ for hot beverages. Both paperboards recently received Nordic Swan approval. They represent a new generation of barrier paperboard that incorporates water-based dispersion barrier coatings on one or both sides that are applied online with curtain/slide coaters as a single layer of multi-layered coatings. Upon collection and sorting, disposable coffee cups made with ISLA board can be composted or recycled together with the fibrous component. Cups, like office papers, are recyclable in the common paper waste streams. Tests have also shown that the ISLA barrier coatings are over $90 \%$ biodegradable upon industrial composting.

\section{Pigmented Coatings}

For pigmented coatings, super-platy clays, or layered silicates (i.e., nanoclays), have been shown to provide the physical barrier to water, oil, and grease. They also provide protection against migration of mineral oil saturated hydrocarbons (MOSH) and mineral oil aromatic hydrocarbons (MOAH) to food packaging (Imerys 2017). However, superplaty kaolin coatings tend to crack at the fold upon creasing and add 5 to $10 \%$ by weight to formulated coatings for paper cups. They have also been blended with bioplastics, such as PLA, but with limitations as such coatings are not the best for high-moisture resistance of $\mathrm{OOH}$ paper coffee cups. Besides achieving technical performance, inclusion of pigments in barrier coatings also depends on the final cost of the formulated coating.

Although water-based resins and dispersion technologies have the advantage that they can be readily adopted to existing coating processes and produce recyclable paper coffee cups, they are only making small and slow inroads to replacing fossil-based liners in coffee cups. At issue is the relatively high raw material and in-use costs required to achieve barrier performance and end-use performance properties. Furthermore, coated cupstock needs to be converted at high speeds, which has proven to be an additional challenge. These challenges make it difficult to broadly and readily displace paper cups lined with fossil-based plastics and some bioplastics. Upon industrial composting, paper cups coated with water-based dispersions demonstrate some degradation, yet they leave behind thermoplastic microparticles, which can still have an adverse environmental impact (Brinton 2016). Recycling with other common papers, such as old corrugating boxes, is considered a more viable end-of-life solution. 


\section{Bioplastics as Replacement for PE Liners}

Unlike petroleum-derived PE, many bioplastics, such as thermoplastic starch, polylactic acid (PLA), polybutylene succinate (PBS), polyhydroxyalkanoates (PHA), and their blends, are industrially compostable. Thermoplastic starch is water-sensitive and its application in barrier coating may only be in blends with other polymers. Biodegradable aliphatic polyesters, such as PLA and PBS, are typically produced by condensation reactions. For high-molecular weight biodegradable polymers, ring opening polymerization is preferred (Vroman and Tighzert 2009). Polylactic acid is produced from a series of natural $\alpha$-hydroxy acids with bacterial fermentation from corn or sugar cane, while PBS is the product of the condensation reaction of succinic acid and 1-4 butanediol (BDO) based on petroleum or sugars. Both plastics are biodegradable in industrial composting facilities. Polyhydroxyalkanoates are linear polyesters produced by bacterial fermentation of sugars or lipids. Their most common type is the polyhydroxy-butyrate (PHB) from sugar cane. Plastics with PHAs are readily biodegradable in soil, wetlands, marine water, septic and municipal solid waste facilities, and even in cold seawater. They are also US-FDA approved for food contact in packaging. Although the potential of PHA to replace fossil-based PE liner has been recognized from many years ago, its economically attractive large-volume production has not yet materialized, making it difficult to compete in the market against fossil-based plastics (Laird 2019).

Table 2. Categorizing Biodegradability of Bioplastics Currently in the Market and Under Commercial Development (Bergsma et al. 2017)

\begin{tabular}{|c|c|}
\hline Degree of Biodegradation & Material \\
\hline Readily biodegradable & PHA \\
(in seawater or residential composting) & Regenerated cellulose \\
\hline Biodegradable at large scale & PLA \\
(municipal/industrial composting) & PLA-PHA blends \\
& Thermoplastic Starch (TPS) \\
& TPS-PLA blends \\
Bio-PBS \\
\\
TPS-bio-PBS blends \\
TPS-PHA blends
\end{tabular}

All these polymeric resins can be applied in existing extrusion equipment optimized for their processing; hence, they all represent potentially commercially viable solutions that can replace fossil-based PE liners. In many cases, resins are formulated in blends with other bioplastics and additives to improve their processability during extrusion. Attractiveness of their use is that the final product is industrially compostable and biodegradable, with several compostable at the residential level (Table 2). Most often, industrial composting systems are required to provide the high temperature $\left(>49^{\circ} \mathrm{C}\right)$ required for practical composting to biodegrade within a reasonable time. The rate of biodegradability of bioplastics depends on their processing conditions, molecular weight, additives, and crystallinity (Garrison et al. 2016).

The drive to reduce pollution has generated considerable interest within the coffee cup value chain to exploit the properties of bioplastics and introduce biodegradable coffee cups to the market. For example, UK-based Biopac Limited has commercialized compostable hot cups using paperboard that is certified by the Forest Stewardship Council (FSC) and a specially formulated starch-based coating that provides barrier properties. The 
company also offers a double-layered version for enhanced thermal insulation. World Centric $^{\circledR}$, a California Benefit Corporation, offers three lines of hot paper cups, each using cupstock lined with Ingeo ${ }^{\text {TM }}$ PLA, made by NatureWorks ${ }^{\circledR}$, as the barrier. Similarly, Pactiv produces the Earthchoice ${ }^{\mathrm{TM}}$ cups lined with Ingeo. Natur-Tec, a business unit of Northern Technologies International Corporation, in collaboration with ITC India's Paperboard and Specialty Paper Division (ITC PSPD), successfully commercialized a modified-PLA coated cup that is also certified compostable by the Biodegradable Products Institute (BPI) (Manjure 2011). Their Omega Bev ${ }^{\circledR}$ products are either PLA-based or made with a synthetic resin and polydimethylsiloxane coatings, giving water resistance and heat sealability. Ecotainer ${ }^{\circledR}$ by International Paper Foodservice (now Graphic Packaging International) also uses Ingeo PLA coating, making coffee cups compostable in industrial facilities. A PLA lined product made by WestRock is the TruServ ${ }^{\mathrm{TM}}$ Compostable Cupstock. Compostable biopolymer is also used as a barrier coating in Stora Enso's Cupforma Natura ${ }^{\mathrm{TM}}$ cupstock, a lightweight three-layered fibrous basestock that has the properties for converting it to disposable coffee cups. Earth $\mathrm{Cup}^{\mathrm{TM}}$ by Biodegradable Food Service $^{\mathrm{TM}}$ (US) is a PLA-lined coffee cup that has BPI certification for composting in industrial facilities. Typically, PLA is modified to enhance its thermal stability in extrusion lines and to improve its mechanical properties (e.g., reduce brittleness). Although modified PLA and its blends have gained market share in bioplastic cold beverage cups, they have not yet made a large-scale break into the broader paper coffee cup liner market due to their high in-use cost relative to $\mathrm{PE}$, heavy coatweight required to achieve targeted barrier properties, difficulty in recycling - including contamination of other recyclable plastic streams - and slow biodegradation rates during industrial composting.

While companies are actively introducing biodegradable product lines, pullthrough has been largely slow due to three reasons:

1. Bio-based polymers are expensive relative to the petroleum-derived resins. Use of bio-based polymers increases the unit cost of the cup, which presents a challenge in this highly cost-sensitive market;

2. Very few retail facilities have access to composting, while only a fraction of compost processing facilities accept bioplastics; and

3. The lack of uniform terminologies and standards for biological recycling of biopolymer products.

As a result, many biodegradable products are improperly disposed in landfills or contribute to plastic pollution (McDonald 2019).

\section{Overcoming the Collection Challenge}

Composting bioplastic-based coffee cups is problematic because they contaminate composting streams. As a result, they are not accepted by most of the existing US composting facilities. At this time, only a few hundred of the roughly 4,000 composting sites in the US accept foodservice packaging, and a much smaller portion accepts bioplastics (Wozniacka 2019). The problem is contamination with fossil-based plastics. Where composting facilities do not accept biopolymers, municipalities have to find other alternatives to access biological recycling facilities (McDonald 2019). One solution for bioplastic cup-friendly composting facilities may be to follow the lead of Chulalongkorn University (Bangkok, Thailand), where through their "zero-waste cup" initiative nearly 2 million coffee cups are collected from 17 university canteens annually and processed 
through a central composting facility designed to process the bioplastic. These cups, which biodegrade in the soil even under ambient temperatures, use a PBS-based coating from PTT MMC Biochem, Thailand, marketed under the tradename bioPBS ${ }^{\text {TM }}$ (BioPBS ${ }^{\text {TM }}$ 2016, 2019). The eco-friendly product has been qualified as a coating for cupstock, with sufficient properties for extruder processing, heat sealing, and printing properties that are equivalent to PE. Starbucks has announced pre-market testing of a BioPBS ${ }^{\text {TM}}$-lined cup in selected stores in Vancouver, Seattle, San Francisco, New York, and London (Starbucks 2020A).

Thailand-based Chula Zero Waste offers coffee in paper cups lined with bioPBS sold in $11 \mathrm{OOH}$ canteens so far, bringing 5.7 tons of cups to industrial composts, completely biodegrading within three months. Most recently, under their "be smart, be green" program, Silapakorn University partnered with PTT Global Chemical to promote the use of bioPBS in coated paper cups. A newer bioPBS version biodegrades at ambient conditions of $30{ }^{\circ} \mathrm{C}\left(86{ }^{\circ} \mathrm{F}\right)$ to produce $\mathrm{H}_{2} \mathrm{O}, \mathrm{CO}_{2}$, and biomass without the need of an industrial composting facility. Although industrially compostable, PBS is yet to be produced economically in large volumes across continents, while its high raw materials and manufacturing costs have so far limited its broad application into coffee cups beyond Thailand and southeast Asia.

A number of recyclable coffee cups have been introduced by integrated manufacturers such as WestRock, Stora Enso, Metsä Board Husum, and Kotkamills; and biodegradable cups by Graphic Packaging International, Evergreen Packaging, Lecta, Asia Pulp \& Paper (APP), ITC PSPD, and PTT MMC; as well as by converters like Tetra Laval, ECO Products, Smart Planet Technologies, LBP Manufacturing, Huhtamäki, rePaper, and Walkifoods. They are trying to make recycling of paper coffee cups easy, such as the initiative launched by Huhtamäki introducing QR codes on their cups that lead to recycling possibilities available to a consumer. Other converters, such as Dart Corporation, Pactiv, and Seda Packaging, have made significant commitments to using sustainable raw materials for cup manufacturing. Recyclable coffee cups can now be processed with other papers in recycling papermills, while the ones based on biopolymers or WBBC are over 90\% biodegradable in industrial composting facilities. Exceptions are bioPBS, which is compostable at $30{ }^{\circ} \mathrm{C}$, and PHA, which is readily compostable in any environment. It should be noted, however, that an increase in compostable single-use coffee cups and foodservice packaging can bungle up existing composting processes, instead of increasing commitment of consumers to the more environmentally beneficial practices of reducing and reusing (Wozniacka 2019).

\section{CONCLUDING REMARKS}

Consumer demand for environmentally friendly products has resulted in many parallel worldwide efforts across the value chain to deliver alternatives to plastic-coated paper cups. Although progress has been made, the Holy Grail remains elusive: how to make an easy to use out-of-home $(\mathrm{OOH})$ paper coffee cup that readily disintegrates in a typical ambient environment within a reasonable time, requiring no specialized composting. To this end, raw material suppliers, manufacturers, converters, and brand-owners are delivering a plethora of new products that can eliminate PE in favor of bio-based plastics. These new cup offerings are in many cases compostable and biodegradable in industrial 
facilities. However, high end-product unit costs still remain a challenge to widespread adoption of such solutions.

Although recent progress has been made, recycling and composting infrastructures needed to recover waste cups on a large scale are largely absent. From a cost perspective, there is a premium in-use cost associated with compostable and biodegradable coffee cups. As a result, manufacturers need to fully understand the available technology options so that they can make informed decisions about materials selection, while brand owners need to consider the full life cycle cost of products they use (Changwichan and Gheewala 2020). A recent life cycle study showed that current methods for disposing paper cups has the global environmental footprint of 1.5 million Europeans and that recycling could reduce this impact by 40 percent (Foteinis 2020). The entire value chain needs to work with municipalities, regional communities, and across governments to ensure that a recovery infrastructure is in place to best dispose and process these cups. Only then will it be possible to meet consumer needs while addressing environmental and sustainability goals. However, it is one thing for the consumer to talk about sustainability and demand environmentally friendly product options, and another to practice prudent waste separation practices and be willing to pay a premium for behaviors and selections that support sustainability.

New policies and legislation are driving the change to more sustainable solutions and a circular economy. An example is the recent provisional agreement for an EU directive on single-use plastics to address marine litter: where alternatives are easily available and affordable, and single-use plastic products will be banned from the market, while other products will be limited in their use through reduction in consumption, design and labelling requirements, and waste management/clean-up obligations for producers (European Commission 2019). Approved in June 2019, EU member states have to transpose it within two years. Its implementation requires separate measures to apply to different product categories that include reduction in the use of PE-lined OOH paper coffee cups. In parallel, the UK has already introduced the producer responsibility obligation regulation that essentially taxes producers through purchasing packaging recovery notes (UK Parliament 2017). Currently, there is consideration for further legislation in the UK, Australia, Canada, South Africa, China, India, Singapore, and Taiwan to phase out singleuse fossil-based plastics, including PE-lined $\mathrm{OOH}$ paper coffee cups, within the next five years.

Sustainability commitments and initiatives by brand owners help to identify ideas and accelerate implementation of new innovative solutions in collaboratively finding solutions to the waste problem and designing the next generation coffee cup. In a recent letter by Starbucks' CEO, the company reiterated its commitment to becoming resource positive, storing more carbon than they emit, eliminating waste, and providing cleaner freshwater than they use, and established as a key benchmark replacement of single-use by reusable packaging (Starbucks 2020B). Similar guiding principles have been chartered by other major brand owners in the foodservice industry. In March 2018, Starbucks committed $\$ 10$ million to the NextGen Cup Challenge project, a collaboration with Closed Loop Partners and its Center for the Circular Economy (NextGen Consortium 2020). Since then, the project has been joined by McDonalds, Coca Cola, the Yum! Group, Wendy's, and Nestlé. Its goal is to seek a global end-to-end solution that would allow paper coffee cups around the world to be diverted from landfills and recycled or composted. The consortium awarded accelerator grants to innovators and entrepreneurs working on ideas that could help develop more sustainable cups, while through open innovation inviting industry 
participation and partnerships to implement a global solution. Out of 500 submissions from 50 countries, 29 teams were selected to move to the refinement stage of the Challenge (OpenIDEO 2020). Subsequently, a forum of judges from food and beverage companies picked the 12 most promising ideas and prototypes to move forward to their demonstration stage (Wilson 2019). At the time of this writing, six teams have entered phase five of the project to create manufacture-ready products/services, pitch-ready business plans, and teams for long-term growth. The winners included: Colombier (The Netherlands, Finland) and Footprint (USA) for their innovative barrier coating liners; Solublue (UK) in the new material (plant-based) category; CupClub (UK) for their returnable cup ecosystem scheme; and ReCup (Germany) for their deposit system of reusable (rent-and-return) cups. Demonstrations of large-scale production capability and testing concepts at the consumer level have started in September 2019.

Preference for new materials and cups is for designs that can fit currently available manufacturing processes and recycling process capabilities. Recently, the Confederation of European Paper Industry (CEPI) introduced packaging recyclability guidelines that included alternative barriers from new technologies such as polymer dispersion coated barriers (CEPI 2019). The guidelines emphasized design of barrier products ensuring that (a) the paper component of the package breaks down to single fibers in existing recycling pulpmill equipment, and (b) giving preference to polymers that can be efficiently removed from the fibrous component in existing screening processes. Separately, the National Geographic Society and Sky Ocean Ventures put together the Ocean Plastic Innovation Challenge to source ideas from around the world about designing a better packaging, such as a fully biodegradable coffee cup (Borunda 2019). Results from such efforts would test the true appetite of consumers for a change to sustainable solutions, provide ways to implement the no-single-use plastic policies, and assist in implementing an integrated approach to coffee cups recovery. In the end, the successful adoption of such solutions will provide lasting benefits and advance the circular economy by minimizing cradle-to-cradle resources consumption and carbon footprint.

\section{REFERENCES CITED}

Bergsma, G., De Graaf, L., Nusselder, S., and Odegard, I. (2017). Biobased Plastics in a Circular Economy: Policy Suggestions for Biobased and Biobased Biodegradable Plastics (Report J66), CE Delft, Delft, Netherlands.

Borunda, A. (2019). "Can you solve the plastics problem? New prize invites ideas," National Geographic, (www.nationalgeographic.com/environment/2019/02/plasticinnovation-challenge-prize-clean-ocean/\#close), Accessed 11 Feb 2019.

Brinton, W., Dietz, C., Bouyounan, A., and Matsch, D. (2016). "The environmental hazards inherent in the composting of plastic-coated paper products," Eco-Cycle, (http://www.ecocycle.org/microplasticsincompost), Accessed 3 Jan 2019.

Changwichan, K., and Gheewala, S. (2020). "Choice of materials for takeaway beverage cups towards a circular economy," Sustainable Production and Consumption 22, 3444.

Chaudhuri, S. (2018). "Paper cups become a target in the fight against plastic," Wall Street Journal, (https://www.wsj.com/articles/scrutiny-of-paper-coffee-cups-stacksup-1540810800), Accessed 31 Oct 2018. 
Chung, Y. D., Moore, B. M., and Zhang, Y. (2018). "Method for manufacturing fiberbased produced containers," U. S. Patent No. 9856608.

Confederation of European Paper Industries (CEPI) (2019). "Paper-based packaging recyclability guidelines," (http://www.cepi.org/system/files/public/news_items/193038_Recyclability_A4_EN_20191115.pdf), Accessed 01 March 2020.

Crowther-Alwyn, L. (2019). "Innovative barriers for flexible packaging," in: Proceedings of the PTS Streicherei 2019 Symposium, Munich, Germany.

De Sailly, M. (2018). "Imerys Barrikote water-based barrier formulation for recyclable hot and cold cups," OpenIDEO, (https://challenges.openideo.com/challenge/next-gencup-challenge/ideas/imerys-barrikote-water-based-barrier-formulation-for-recyclablehot-and-cold-cups), Accessed 17 Jan 2020.

DIN EN 13432:2000 (2007). "Requirements for packaging recoverable through composting and biodegradation - Test scheme and evaluation criteria for the final acceptance of packaging," Deutsches Institut für Normung, Berlin, Germany.

European Bioplastics (2017). "Bioplastics packaging: Combining sustainability with performance" (http://docs.european-bioplastics.org/2016/publications/fs/ EUBP_fs_packaging.pdf), Accessed 30 Nov 2019.

European Commission (2019). Directive (EU) 2019/904 of the European Parliament and of the Council of 5 June 2019 on the reduction of the impact of certain plastic products on the environment (https://eur-lex.europa.eu/legal-content/EN/TXT/PDF/? uri=CELEX:32019L0904\&from=EN), Accessed June 19, 2020.

Foteinis, S. (2020). "How small daily changes play a huge role in climate change: The disposable paper cup environmental bane," J. Cleaner Production 255, 120294.

Frugal Pac (2020). "Recyclable coffee cups," (www.frugalpac.com), Accessed 19 Jan 2020.

$\mathrm{Fu}, \mathrm{T}$., and Cook, M. (2017). “Thermally activatable insulating packaging," U. S. Patent No. 9580228.

Garrison, T., Murawski, A., and Quirino, R. (2016). "Bio-based polymers with potential for biodegradability," Polymers 8(7), 262-284. DOI: 10.3390/polym8070262

Hämäläinen, M. (2019). "Plastic-free, easily recyclable paper cups are available," in: Proceedings of the TAPPI PaperCon 2019 Conference, Indianapolis, IN, USA.

Hocking, M. (1994). "Reusable and disposable cups: An energy-based evaluation," Environmental Management 18(6), 889-899. DOI: 10.1007/BF02393618

Hogue, C. (2018). "San Francisco moves to ban food containers made with fluorinated chemicals," Chemical and Engineering News, (https://cen.acs.org/policy/legislation/San-Francisco-moves-ban-food/96/i32), Accessed 04 Feb 2019.

Hutchinson, L. (2019). "Development of more sustainable barrier technology for packaging," in: Proceedings of the TAPPI PaperCon 2019 Conference, Indianapolis, IN, USA.

iMarc (2020). "Paper cups market: Global industry trends, share, size, growth, opportunity and forecast 2020-2025," (https://www.imarcgroup.com/paper-cupsmanufacturing-plant), Accessed 15 April 2020.

Imerys (2017). Formulation Services Brochure: Barrier Against Mineral Oils, Imerys Kaolin Americas, Sandersville, GA, USA.

Ju, L. T., Yoon, C., and Ryu, J. Y. (2017). "A new potential paper resource: Recyclability of paper cups coated with water-soluble polyacrylate latex," Nordic Pulp \& Paper Research Journal 31(1), 155-161. DOI: 10.3183/npprj-2017-32-01-p155-161 
Kamenetz, A. (2010). "The Starbucks cup dilemma," Fast Company, (www.fastcompany.com/1693703/starbucks-cup-dilemma), Accessed 05 Feb 2019.

Laird, K. (2019). "Bioplastics: Promising but pricey," Plastic News, (https://www.plasticsnews.com/article/20190205/NEWS/190209956/bioplasticspromising-but-pricey), Accessed 06 Feb 2020.

Larsson, T., and Emilsson, P. (2019). "Cupstock coated with multilayer WBBC's process \& product performance," in: Proceedings of the PTS Streicherei 2019 Symposium, Munich, Germany.

Lingle, R. (2018). "New paperboard packaging matches foodservice shift in sustainability," Packaging Digest,

(https://www.packagingdigest.com/paperboard/new-paper-pkg-option-matchesfoodsv-sustain-1805), Accessed 28 Dec 2019.

Ma, Y. (2018). "Problems and resolutions in dealing with waste disposable paper cups," Science Progress 101(1), 1-7 (https://doi.org/10.3184/003685017X15129981721365)

Manjure, S. (2011). "PLA for paper coating," Bioplastics Magazine 6(5), 34-37.

McDonald, N. (2019). "Biological recycling of biodegradable plastics," Biocycle 60(7), 32-34, 36.

Minter, A. (2014). "Why Starbucks won't recycle your cup," Bloomberg News, (www.bloomberg.com/view/articles/2014-04-07/why-starbucks-won-t-recycle-yourcup), Accessed 05 Feb 2019.

Mohan, K., and Koukoulas, A. A. (2004). "Low density paper and paperboard articles," U.S. Patent No. 6802938.

Mouw, S., Schwartz, L., and Yakorsky, S. (2020). "State of curbside report," The Recycling Partnership, (https://recyclingpartnership.org/stateofcurbside/), Accessed 13 Feb 2020.

Narayan, R. (2011). "Carbon footprint of biopolymers using biocarbon content analysis and life-cycle assessment," MRS Bulletin 36(9), 716-721. DOI:

$10.1557 / \mathrm{mrs} .2011 .210$

NextGen Consortium (2020). "Accelerating the future of the fiber," (https://www.nextgenconsortium.com), Accessed 10 Feb 2020.

Nossa Familia Coffee (2019). "Sustainability and transparency report," (https://static1.squarespace.com/static/5419e3c7e4b090c9db3d42ca/t/5d0bc51aa2343 f00014258ab/1561052454593/Sustainability-Report-2018-19_Nossa-FamiliaCoffee.pdf), Accessed 10 Feb 2020.

OpenIDEO (2020). "NextGen cup challenge: Short List," OpenIDEO, (https://mediaopenideo-rwd.oiengine.com/attachments/8efc2ce0-e61f-4a4c-b2f365bbd6738d79.pdf ), Accessed 12 Feb 2020.Peters, A. (2018). "Starbucks recycled 23 million old coffee cups into new cups," FastCompany Magazine, (https://www.fastcompany.com/90270871/starbucks-recycled-25-million-old-papercoffee-cups-into-new-cups), Accessed 28 Nov 2019.

Piwowar, A., Einsla, B., Ellison, C., Fowler, H., Katzenstein, J., Leitinger, J., Mason, J., Roper, J., Rosen, K., and Smith, R. (2019). "Optimizing performance of polyolefin based waterborne barrier coatings for cupstock applications," in: Proceedings of the TAPPI PaperCon 2019 Conference, Indianapolis, IN, USA.

ProCarton (2019). "Retail trade, brands and packaging - The trends 2019," (www.procarton.com/retail-trade-brands-and-packaging-the-trends-for-2019/), Accessed 20 May 2019. 
Rao, R. (2009). "Polyolefin dispersion - A new vistas for flexible packaging," in: Proceedings of the TAPPI PLACE 2009 Conference, Mumbai, India.

Reed,F. (2018). "PCRRG reports huge increase in coffee cup recycling," PCRRG, (www.pcrrg.uk/news.html), Accessed 20 Jan 2019.

Ritter, S. (2015). "The shrinking case for fluorochemicals," Chemical \& Engineering News 93(28), 27-29. DOI: 10.1021/cen-09328-scitech1

Rodden, G. (2018). “A perennial problem solved,” Paper 360, (https://www.paper360digital.com/ppis/may_june_2018/MobilePagedArticle.action?articleId=1395357\#artic leId1395357), Accessed 27 July 2018.

Sherriff, L. (2019). "This recyclable coffee cup is made from 100\% recyclable paper," Forbes, (www.forbes.com/sites/lucysherriff/2019/11/16/this-recyclable-coffee-cup-ismade-from-100-recyclable-paper/\#3db62c1d4c52), Accessed 28 Dec 2019.

Shim, M.-S. (2016). “Aqueous copolymeric latex comprising multi-functional silicone, preparation thereof, and food, packaging container using the same" Korean Patent No. 10-2016-0050980.

Stanssens, D. (2017). "Barrier coating for PE-free paper cups," in: Proceedings of the PTS Coating 2017 Symposium, Munich, Germany.

Starbucks Corporation (2020A). "Starbucks trials a NextGen cup solution," (https://stories.starbucks.com/stories/2020/starbucks-trials-a-"-cupsolution/), Accessed 4 Feb 2020.

Starbucks Corporation (2020B). "A message from Starbucks CEO Kevin Johnson: Starbucks new sustainability commitment," (https://stories.starbucks.com/stories/2020/message-from-starbucks-ceo-kevinjohnson-starbucks-new-sustainability-commitment), Accessed 10 March 2020.

Streeter, V., and Platt, B. (2017). "Residential food waste collection access in the US," (https://www.biocycle.net/2017/12/06/residential-food-waste-collection-access-u-s/), Accessed 11 Jan 2019.

Tame, J. (2020). "European packaging preferences 2020: A European study of consumer preferences, perceptions, and attitudes towards packaging," A TwoSides Report, Daventry, UK.

UK Parliament (2017). "Targets and policy for coffee cup waste reduction," (publications.parliament.uk/pa/cm201719/cmselect/cmenvaud/657/65706.htm), Accessed 27 Dec 2019.

United States Environmental Protection Agency (US EPA) (2017). "Paper and paperboard: Material-specific data," (www.epa.gov/facts-and-figures-aboutmaterials-waste-and-recycling/paper-and-paperboard-material-specific-data), Accessed 24 Jan 2020.

Vähä-Nissi, M., Lahti, J., Savolainen, A., Rissa, K., and Lepisto, T. (2001). "New waterbased barrier coatings for paper and paperboard," Appita Journal 54(2), 106-115.

Vercammen, Y. (2019). "Towards fully sustainable food packaging," in: Proceedings of the PTS Streicherei 2019 Symposium, Munich, Germany.

Vroman, I., and Tighzert, L. (2009). "Biodegradable polymers," Materials 2(2) 307-344. DOI: $10.3390 / \mathrm{ma} 2020307$

Webb, H. K., Arnott, J., Crawford, R., and Ivanova, E. (2013). "Plastic degradation and its environmental implications with special reference to poly(ethylene terephthalate)," Polymers 5(1), 1-18. DOI: 10.3390/polym5010001

Wilson, M. (2019). "Starbucks and McDonald's are testing these radical cups of the future," Fast Company, (https://www.fastcompany.com/90311549/starbucks-and- 
mcdonalds-are-testing-these-compostable-cups-of-the-future), Accessed 01 March 2019.

Wozniacka, G. (2019). "Plastic to-go containers are bad, but are the alternatives any better?," Civil Eats, (https://civileats-

com.cdn.ampproject.org/c/s/civileats.com/2020/01/14/plastic-to-go-containers-arebad-but-are-the-alternatives-any-better/amp/), Accessed 14 Jan2020.

Yoon, C. (2019). "Paper coating material having environment-friendly, water-proof and oil-proof properties, and method of manufacturing the same," U. S. Patent No. 10184067.

Article submitted: March 12, 2020; Peer review completed: June 13, 2020; Revised version received and accepted: June 22, 2020; Published: June 25, 2020.

DOI: 10.15376/biores.15.3.Triantafillopoulos 